\title{
Traffic Accidents with Motorcycles and their Relationship to Mortality ${ }^{1}$
}

\author{
Nelson Luiz Batista de Oliveira² \\ Regina Marcia Cardoso de Sousa ${ }^{3}$
}

This study characterizes traffic accidents involving motorcycles according to local conditions, data concerning the type of accident, date and time, and identifies among these variables those associated with the death of victims. This retrospective study uses data from traffic collision reports from 2004 and death records from the institute of forensic medicine. A total of $99.4 \%$ of the events occurred in urban areas, where illumination $(87.4 \%)$, weather conditions $(80.6 \%)$; and traffic signs $(70.6 \%)$ were satisfactory. Collisions between motorcycles and cars or pickup trucks prevailed $(55.5 \%)$, followed by motorcycle falls $(18.0 \%)$. In relation to the type of collision, the highest percentage was observed in broadside collision category $(35.2 \%)$. There were differences between the groups of fatalities and survivors in relation to the area and illumination in the collision's site, in addition to the types of collision and impact. The conclusion is that local conditions and types of collision and impact stand out among the multiple variables defining the severity of accidents involving motorcycles.

Descriptors: Accidents, Traffic; Mortality; External Causes.

\footnotetext{
${ }^{1}$ Paper extracted from Doctoral Dissertation "Fatores associados ao risco de lesões e óbito de motociclistas envolvidos em ocorrências de trânsito", presented to Programa de Pós-graduação em Enfermagem, Escola de Enfermagem, Universidade de São Paulo, SP, Brazil.

2 RN, Ph.D. in Nursing, Adjunct Professor, Departamento de Enfermagem, Universidade Estadual de Maringá, PR, Brazil. E-mail: nlboliveira@uem.br.

${ }^{3}$ RN, Ph.D. in Nursing, Associate Professor, Escola de Enfermagem, Universidade de São Paulo, SP, Brazil. E-mail: vian@usp.br.
}

Corresponding Author:

Nelson Luiz Batista de Oliveira

Rua Rio Parnaiba, 44

Bairro: Jardim Novo Oasis

CEP: 87043-330, Maringá, PR, Brasil

nlboliveira@uem.br 


\section{Ocorrências de trânsito com motocicleta e sua relação com a mortalidade}

Os objetivos deste estudo foram caracterizar as ocorrências de trânsito com motocicleta, segundo condições locais, dados relacionados ao tipo de acidente, data e hora, além de identificar, entre essas variáveis, aquelas que se associaram à morte das vítimas. Como método foi usado o estudo retrospectivo, utilizando dados dos Boletins de Ocorrência de Trânsito, referentes ao ano 2004, e os registros de óbito do Instituto Médico Legal. Tem-se como resultados que $99,4 \%$ das ocorrências aconteceram em área urbana, em locais onde as condições de luminosidade $(87,4 \%)$, condição meteorológica $(80,6 \%)$ e sinalização $(70,6 \%)$ eram satisfatórias. Predominou a colisão de motocicleta com carro ou caminhonete $(55,5 \%)$ e as quedas de motocicleta foram a seguir as mais frequentes $(18,0 \%)$. No tipo de impacto, o maior percentual foi observado na categoria abalroamento transversal $(35,2 \%)$. O grupo de mortos diferiu em relação aos sobreviventes quanto à área e luminosidade do local da ocorrência, além do tipo de acidente e impacto. Concluise que as condições locais, tipos de acidente e impacto destacam-se entre as múltiplas dimensões que envolvem a gravidade das ocorrências com motociclistas.

Descritores: Acidentes de Trânsito; Mortalidade; Causas Externas.

\section{Ocurrencias de tránsito con motocicleta y su relación con la mortalidad}

Se tuvo por objetivo caracterizar las ocurrencias de tránsito con motocicleta, según condiciones locales, datos relacionados al tipo de accidente, fecha y hora, además de identificar entre esas variables las que se asociaron con la muerte de las víctimas. Se trata de un estudio retrospectivo utilizando datos de los Boletines de Ocurrencia de Tránsito referentes al año de 2.004 y los registros de muerte del Instituto Médico Legal. El 99,4\% de las ocurrencias sucedieron en área urbana, en locales donde las condiciones de luminosidad $(87,4 \%)$, condición meteorológica $(80,6 \%)$ y señalización $(70,6 \%)$ eran satisfactorias. Predominó la colisión de motocicleta con automóvil o camioneta $(55,5 \%)$ y las caídas de motocicleta fueron las más frecuentes $(18,0 \%)$. En el tipo de impacto, el mayor porcentaje fue observado en la categoría colisión transversal $(35,2 \%)$. El grupo de muertos difirió en relación a los sobreviventes en cuanto al área y luminosidad del local de la ocurrencia, además del tipo de accidente e impacto. Se concluye que las condiciones locales, tipos de accidente e impacto se destacan entre las múltiples dimensiones que envuelven la gravedad de las ocurrencias con motociclistas.

Descriptores: Accidentes de Tránsito; Mortalidad; Causas Externas.

\section{Introduction}

As automobiles are increasingly incorporated into the daily life of communities, traffic collisions emerge as an important social and economic problem. Since the second half of the $20^{\text {th }}$ century, automobiles have been responsible for an extremely high percentage of mortalities and also temporary and permanent disabilities occurring indiscriminately among nations around the world(1).

An increasing number of victims involved in motorcycle accidents has been observed in recent decades among traffic collisions. This vehicle has gained increased acceptance and approval of the population for being fast, economical and of low cost ${ }^{(2)}$. Jointly with cyclists and pedestrians, motorcyclists are extremely 
exposed and stand out in the statistics of accidents that lead to severe injuries and death( ${ }^{(3)}$.

Given this scenario and considering the importance of motorcycle collisions for the occurrence of injuries and death, both due the incidence and also due to the severity and consequences of such accidents, this study characterizes the occurrence of collisions with motorcycles according to local conditions, data related to the type of collision, date and time, and also identifies among these variables those associated with the death of victims.

Knowledge concerning the scenario of motorcycle collisions and consequent mortality can contribute not only to develop interventions and programs to prevent injuries and death, but also to implement, ground and develop care programs for individuals involved in these events and provide a precise diagnosis of the situation to conduct further studies to serve as a reference for multidisciplinary teams and establish procedures to diminish the incidence of these events in the population.

\section{Method}

This is an epidemiological, descriptive, analytical and retrospective study with a longitudinal approach ${ }^{(4)}$. Maringá, the city where the study was developed, has an estimated population of 335,511 inhabitants and is located in the northeast of Paraná, Brazil and is the state's third largest city. There is currently a fleet of 50,631 motorcycles and 122,963 automobiles in the city.

The data, except those related to mortality, were obtained from Traffic Collision reports (TCR) issued by the police. Traffic collisions that occurred in Maringá, PR involving motorcycles between January $1^{\text {st }}$ and December $31^{\text {st }} 2004$ were included.

In each of these events, the police issues a TCR including information of each vehicle involved in the event and their respective occupants. The following variables were retrieved from this document: date, time and day of the week, number and type of vehicles involved, area (urban or rural), type of collision and conditions of the site where the accident occurred (illumination, weather conditions, and traffic signs).

The records concerning 2004 were drawn from the files and each of the reports were consulted by month. When the report indicated a motorcycle collision, its information was transcribed into a specific data collection instrument, developed for this purpose. All the reports related to the study's period were consulted and revised twice to include all the events and to confirm data.

The coding for this type of collision was established according to ICD-10 (V20-V28)(5). Deaths caused by collisions up to six months after the traffic accident were identified through a search in the records of the Institute of forensic medicine.

The study was approved by the Permanent Committee of Research Ethics Involving Human Subjects at the State University of Maringá (Protocol No 354/2005). The $4^{\text {th }}$ Military Police Battalion and the Institute of forensic medicine authorized the use of databases.

Collected data were stored in two computer databases in EXCEL ${ }^{\circledR}$. In one database, the units of analysis were the traffic collisions and stored data permitted characterizing the motorcycle collisions. These same data were included in the other database, but the units of analysis were the motorcyclists involved in these events and the variable 'mortality' was included in this set of information.

Statistica Software version $7.1^{\circledR}$ and the Statistical Analysis System (SAS - 9.1) ${ }^{\circledR}$ were used in the analysis and interpretation of results. Bivariate analysis and Chi-square test were used to compare groups of dead individuals and survivors. Fisher's exact test ( $p$ ) was used in the cases in which more than $20 \%$ of the expected frequency in the contingent tables was lesser or equal to five.

\section{Results}

\section{Characterization of reported traffic collisions}

A total of 1,951 traffic collisions were identified in 2004 in Maringá through the TCR: 2,362 motorcyclists were involved, both riders and passengers. There was the participation of 2,052 motorcycles. The daily average of occurrences, regardless of the type of the vehicle involved, was 5.3 and the monthly average was 162 .

The analysis of the distribution of motorcycle collisions according to local characteristics showed the almost all the accidents occurred in urban areas (99.4\%); most with appropriate illumination (87.4\%); good weather conditions (80.6\%); and in places where traffic signs were present (70.6\%). Absence of information concerning illumination was observed in $3.7 \%$ of the events; weather conditions at the time of the accident were not recorded in $3.6 \%$; and lack of information in relation to traffic signaling was observed in $6.8 \%$. Hence, 
data indicate that $0.6 \%$ of the events occurred in rural areas; $8.9 \%$ in poorly illuminated places; in $15.8 \%$ with poor weather conditions; and in $22.5 \%$ of the cases, the site was poorly marked with signals.

Table 1 presents the distribution of traffic collisions according to the number of vehicles involved in each event.

Table 1 - Distribution of traffic collisions with motorcycles $(n=1,951)$ according to the number of vehicles involved and type of collision and impact. Maringá, PR, Brazil 2004

\begin{tabular}{clcc}
\hline Variables & \multicolumn{1}{c}{ Categories } & $\mathbf{N}^{\circ}$ & \% \\
\hline No vehicle involved & One & 557 & 28.6 \\
& Two & 1327 & 68.0 \\
& Three or more & 67 & 3.4 \\
Type of accident & Motorcycle x car/truck & 1082 & 55.5 \\
& Motorcycle fall & 351 & 18.0 \\
& Motorcycle x running over a & 172 & 8.8 \\
& pedestrian/animal & 112 & 5.7 \\
& Motorcycle x heavy vehicle & 105 & 5.4 \\
& Motorcycle x non-motor vehicle & 95 & 4.9 \\
& Motorcycle x motorcycle & 34 & 1.7 \\
& Motorcycle x fixed object & 686 & 35.2 \\
Type of impact & Cross collision & 351 & 18.0 \\
& Motorcycle fall & 310 & 16.0 \\
& Lateral collision & 246 & 12.6 \\
& Rear-end collision & 130 & 6.6 \\
& Collision with pedestrian & 95 & 4.9 \\
& Multiple impacts & 57 & 2.9 \\
& Head-on collision & 42 & 2.1 \\
& Collision with animal & 34 & 1.7 \\
\hline & Collision with a fixed object & &
\end{tabular}

Source: Military Police's Traffic collision report

According to data in Table 1, accidents with two vehicles predominated: 1,327 collisions, that is, $68.0 \%$ of the total. The number of vehicles involved in accidents varied from one to five.

Table 1 also displays the type of accident and impact. More than half of the accidents refer to collision of a motorcycle with a car or a pickup truck: $55.5 \%$ of the total. Motorcycle falls were the second (18.0\%) most frequent accident with 351 events. Almost all accidents, 103 out of 105 events, in the category 'collision of motorcycle with non-motor vehicle' occurred with pedalpowered vehicles.

Considering the type of impact, the largest percentage was observed in the category 'broadside collision' (35.2\%). 'Side collision' was also a frequent accident $(16.0 \%)$ after motorcycle falls (18.0\%).

In relation to the time when the accident occurred, data from Table 2 show that the highest concentration of events occurred between $12 \mathrm{pm}$ and 5:59pm followed by the period between $6 \mathrm{pm}$ and $11: 59 \mathrm{pm}$ (36.5\% and $30.7 \%$ respectively).

Table 2 - Distribution of traffic collisions with motorcycles $(n=1.951)$ according to date and time. Maringá, PR, Brazil - 2004

\begin{tabular}{llcc}
\hline \multicolumn{1}{c}{ Variables } & \multicolumn{1}{c}{ Categories } & $\mathbf{N}^{\mathbf{0}}$ & $\%$ \\
\hline Time & 6am to 11:59am & 504 & 25.8 \\
& 12pm to 5:59pm & 713 & 36.5 \\
& 6pm to 11:59pm & 600 & 30.7 \\
& 12am to 5:59am & 134 & 7.0 \\
& Sunday & 210 & 10.8 \\
& Monday & 259 & 13.3 \\
& Tuesday & 285 & 14.6 \\
& Wednesday & 278 & 14.2 \\
Month & Thursday & 265 & 13.6 \\
& Friday & 330 & 16.9 \\
& Saturday & 324 & 16.6 \\
& January & 129 & 6.7 \\
& February & 128 & 6.5 \\
& March & 181 & 9.3 \\
& April & 142 & 7.3 \\
& May & 155 & 7.9 \\
& June & 176 & 9.0 \\
& July & 148 & 7.6 \\
& August & 196 & 10.1 \\
& September & 163 & 8.4 \\
& October & 189 & 9.7 \\
& November & 171 & 8.7 \\
& December & 173 & 8.8 \\
\hline
\end{tabular}

Source: Military Police's Traffic collision report

The frequency of collisions considerably increases on the weekends. It is almost the same on Fridays and Saturdays ( $16.9 \%$ and $16.6 \%$ respectively), though the lowest frequency of accidents was observed on Sundays $(10.8 \%)$. In relation to the months of the year, the highest percentages were observed in March, August and October (9.3\%, $10.1 \%$ and $9.7 \%$, respectively).

Deaths of motorcycle riders were recorded in 27 traffic collision reports (1.4\% of the total). Four motorcyclists died in two events, totaling 29 fatalities.

\section{Comparison of dead motorcyclists and survivors according to the collisions characteristics}

Even though the variables are related to the characteristics of the events, the unit of the study in the next set of analyses was always motorcyclists ( $n=$ 2,362 ). Table 3 shows that fatalities were proportionally more frequent than individuals who survived in rural areas and in sites with inappropriate illumination and poor traffic signs. A statistically significant association was found only in relation to the variables 'site of the event' and 'illumination'. 
Table 3 - Distribution of motorcyclists involved in traffic collisions $(n=2,362)$, dead and survivors and $p$ values, according to the site characteristics. Maringá, PR, Brazil - 2004.

\begin{tabular}{|c|c|c|c|c|c|c|}
\hline \multirow{3}{*}{ Variables } & \multirow{3}{*}{ Categories } & \multicolumn{4}{|c|}{ Motorcycles } & \multirow{3}{*}{$\mathbf{p}$} \\
\hline & & \multicolumn{2}{|c|}{ Fatalities } & \multicolumn{2}{|c|}{ Survivors } & \\
\hline & & $\mathbf{N}^{\circ}$ & $\%$ & $\mathbf{N}^{\circ}$ & $\%$ & \\
\hline \multirow[t]{2}{*}{ Area $(2,362)$} & Urban & 25 & 86.0 & 2319 & 99.4 & $<0.0001$ \\
\hline & Rural & 4 & 14.0 & 14 & 0.6 & \\
\hline \multirow[t]{2}{*}{ Illumination $(2,268)^{\star}$} & Appropriate & 21 & 77.8 & 2022 & 90.2 & 0.0445 \\
\hline & Inappropriate & 6 & 22.2 & 219 & 9.8 & \\
\hline \multirow[t]{2}{*}{ Weather condition $(2,270)^{*}$} & Good & 24 & 85.7 & 1885 & 84.1 & 1.0000 \\
\hline & Poor & 4 & 14.3 & 357 & 15.9 & \\
\hline \multirow[t]{2}{*}{ Traffic Signs $(2,190)^{*}$} & Present & 17 & 63.0 & 1626 & 75.2 & 0.1771 \\
\hline & Absent & 10 & 37.0 & 537 & 24.8 & \\
\hline
\end{tabular}

Source: Military Police's Traffic collision report

*The difference between the total number and that observed refer to non-reported data.

Data from Table 4 show that variables, type occurrence of fatalities. of accident and impact were associated with the

Table 4 - Distribution of motorcyclists involved in traffic collisions $(n=2,362)$, fatalities and survivors and $p=v a l u e s$, according to the number of vehicles involved, type of accident and impact. Maringá, PR, Brazil - 2004

\begin{tabular}{|c|c|c|c|c|c|c|}
\hline \multirow{3}{*}{ Variables } & \multirow{3}{*}{ Categories } & \multicolumn{4}{|c|}{ Motorcyclists } & \multirow{3}{*}{$\mathbf{p}$} \\
\hline & & \multicolumn{2}{|c|}{ Fatalities } & \multicolumn{2}{|c|}{ Survivors } & \\
\hline & & $\mathbf{N}^{\circ}$ & $\%$ & $\mathbf{N}^{\circ}$ & $\%$ & \\
\hline \multirow[t]{3}{*}{ No of involved vehicles } & One & 8 & 27.5 & 657 & 28.2 & 0.5573 \\
\hline & Two & 19 & 65.6 & 1584 & 67.9 & \\
\hline & Three or more & 2 & 6.9 & 92 & 3.9 & \\
\hline \multirow[t]{7}{*}{ Type of accident } & Motorcycle $\mathrm{x}$ Running over a pedestrian or animal & - & - & 190 & 8.1 & $<0.0001$ \\
\hline & Motor vehicle $\mathrm{x}$ non-motorized vehicle & - & - & 118 & 5.0 & \\
\hline & Motorcycle x Motorcycle & 3 & 10.4 & 213 & 9.1 & \\
\hline & Motorcycle $\mathrm{x}$ car/truck & 9 & 31.0 & 1232 & 53.0 & \\
\hline & Motorcycle $\mathrm{x}$ heavy vehicle & 9 & 31.0 & 116 & 5.0 & \\
\hline & Motorcycle $\mathrm{x}$ fixed object & 4 & 13.8 & 36 & 1.5 & \\
\hline & Motorcycle fall & 4 & 13.8 & 428 & 18.3 & \\
\hline \multirow[t]{9}{*}{ Type of impact } & Lateral collision & 3 & 10.4 & 377 & 16.1 & $<0.0001$ \\
\hline & Cross collision & 8 & 27.5 & 832 & 35.7 & \\
\hline & Head-on collision & 4 & 13.8 & 63 & 2.8 & \\
\hline & Rear-end collision & 2 & 6.9 & 288 & 12.3 & \\
\hline & Collision with fixed object & 4 & 13.8 & 36 & 1.5 & \\
\hline & Multiple impacts & 4 & 13.8 & 119 & 5.1 & \\
\hline & Collision with pedestrian & - & - & 139 & 6.0 & \\
\hline & Collision with animal & - & - & 51 & 2.2 & \\
\hline & Motorcycle fall & 4 & 13.8 & 428 & 18.3 & \\
\hline
\end{tabular}

Source: Military Police's Traffic Collision Report

The percentage of fatalities was higher than survivors in collisions with heavy vehicles, fixed objects and between motorcycles. There were no deaths of motorcyclists in run overs or collisions with non- motorized vehicles. In relation to the type of impact, head-on collision, collision with a fixed object, and multiple impacts were the most frequent in the group of motorcyclist fatalities.

Table 5 - Distribution of motorcyclists involved in traffic collisions $(n=2,362)$, fatalities and survivors and $p=v a l u e s$, according to date and time. Maringá, PR, Brazil - 2004

\begin{tabular}{|c|c|c|c|c|c|c|}
\hline \multirow{3}{*}{ Variables } & \multirow{3}{*}{ Categories } & \multicolumn{4}{|c|}{ Motorcyclists } & \multirow{3}{*}{ p } \\
\hline & & \multicolumn{2}{|c|}{ Fatalities } & \multicolumn{2}{|c|}{ Survivors } & \\
\hline & & $\mathrm{N}^{\circ}$ & $\%$ & $\mathbf{N}^{\circ}$ & $\%$ & \\
\hline \multirow[t]{4}{*}{ Time $(n=2,362)$} & 6am to $11: 59 \mathrm{am}$ & 6 & 20.7 & 584 & 25.0 & 0.1004 \\
\hline & $12 \mathrm{pm}$ to $5: 59 \mathrm{pm}$ & 9 & 31.1 & 833 & 35.8 & \\
\hline & $6 \mathrm{pm}$ to $11: 59 \mathrm{pm}$ & 8 & 27.5 & 748 & 32.0 & \\
\hline & 12am to $5: 59 a m$ & 6 & 20.7 & 168 & 7.2 & \\
\hline
\end{tabular}


Table 5 - (continuation)

\begin{tabular}{|c|c|c|c|c|c|c|}
\hline \multirow{3}{*}{ Variables } & \multirow{3}{*}{ Categories } & \multicolumn{4}{|c|}{ Motorcyclists } & \multirow{3}{*}{ p } \\
\hline & & \multicolumn{2}{|c|}{ Fatalities } & \multicolumn{2}{|c|}{ Survivors } & \\
\hline & & $\mathbf{N}^{\circ}$ & $\%$ & $\mathbf{N}^{0}$ & $\%$ & \\
\hline \multirow{7}{*}{ Day of the week $(n=2,362)$} & Sunday & 3 & 10.4 & 270 & 11.6 & 0.1201 \\
\hline & Monday & 1 & 3.4 & 307 & 13.2 & \\
\hline & Tuesday & 3 & 10.4 & 337 & 14.4 & \\
\hline & Wednesday & 6 & 20.6 & 326 & 14.0 & \\
\hline & Thursday & 4 & 13.8 & 303 & 13.0 & \\
\hline & Friday & 2 & 6.9 & 402 & 17.2 & \\
\hline & Saturday & 10 & 34.5 & 388 & 16.6 & \\
\hline \multirow[t]{12}{*}{ Month $(n=2,362)$} & January & 2 & 6.9 & 154 & 6.6 & 0.1756 \\
\hline & February & - & - & 159 & 6.8 & \\
\hline & March & 5 & 17.2 & 215 & 9.2 & \\
\hline & April & 1 & 3.4 & 167 & 7.2 & \\
\hline & May & 5 & 17.2 & 178 & 7.6 & \\
\hline & June & 1 & 3.4 & 201 & 8.6 & \\
\hline & July & 2 & 6.9 & 184 & 7.9 & \\
\hline & August & 6 & 20.8 & 229 & 9.8 & \\
\hline & September & 2 & 6.9 & 202 & 8.7 & \\
\hline & October & - & - & 232 & 9.9 & \\
\hline & November & 3 & 10.4 & 204 & 8.8 & \\
\hline & December & 2 & 6.9 & 208 & 8.9 & \\
\hline
\end{tabular}

Source: Military Police's Traffic Collision Report

The results related to date and time when the events occurred with and without death show that no statistically significant association was found among these variables (Table 5). It is, however, worth noting that in the group of fatalities, collisions mostly frequently occurred during the night ( $20.7 \%$ compared to $7.2 \%$ ), on Saturdays (34.5\% compared to $16.6 \%$ ), and in August, March and May $(20.8 \%, 17.2 \%$ and $17.2 \%$ compared to $9.8 \%, 9.2 \%$ and $7.6 \%$ respectively).

\section{Discussion}

The number of vehicles in circulation, disrupted traffic, lack of surveillance, poor condition of vehicles, careless drivers, and impunity of offenders, significantly contribute to traffic collisions among the population of motorcyclists(6). Additionally, events that involve motorcycles are particularly more dangerous because when a vehicle collides with a motorcycle, motorcyclists are the victims who present the highest frequency of severe injuries and deaths ${ }^{(7-8)}$.

There were in 2004, 916.9 motorcycles for each 10,000 inhabitants in Maringá. Records of the police showed there were 1,951 traffic collisions involving motorcyclists in 2004. Deaths occurred in 27 (1.4\%) accidents with 29 fatalities. Among the 29 victims, 11 died at the accident site and 18 in the hospital. Most deaths $(68.9 \%)$ occurred in the first hours after the accident.

The group of fatalities differed from the survivors when the area and illumination in the site of the accident were analyzed. A larger proportion of fatalities were observed in rural areas and in places where illumination was inappropriate.

Other authors report that the conditions of victims in rural areas are likely to be more severe than in urban areas due to the high speed developed in rural areas and lack of appropriate traffic signs and surveillance ${ }^{(9)}$.

Road illumination is an important factor related to motorcycle collisions. Data from a study carried out in China showed that illumination is related to fatal accidents and severity of injuries, though the author found a larger proportion of fatal accidents and more severe injuries when appropriate illumination was present (44\%) in comparison to sites with poor illumination (27\%) and daylight $(21 \%)^{(10)}$.

The conclusion in this study is that local conditions of where traffic collisions occur contribute more to the frequency of accidents than to the severity of motorcycle accidents; unfavorable local conditions lead drivers to be more careful. Additionally, appropriate conditions described in most of the events may have minimized the influence of weather conditions on the consequences of accidents. It is worth noting that Maringá is a city with planned roads and that has good weather conditions most of the year.

In relation to the type of accident, this study indicates that the most frequent were collisions with automobiles or pickup trucks, followed by falls. The predominant impact was broadside collision; side and rear-end collisions stood out after falls. The type of 
accident and impact were associated with mortality.

More than half of the fatal accidents resulted from the collision of two vehicles, one motorcycle and another vehicle in movement, generally, passenger cars or heavy vehicles. The main factor in this type of event is difficulty on the part of the other vehicles' drivers in noticing the proximity of motorcycles and appropriately deciding the time to act to avoid colliding. Motorcycles are narrow, which hinders the visibility of other drivers who have difficulty recognizing their proximity ${ }^{(11)}$.

The frequency of deaths in this study was considerably higher in collisions with fixed objects, heavy vehicles, and head-on collisions. Head-on collisions accounted for a high percentage of severe injuries and deaths in a study conducted in California, USA(11). Collision with another motorized vehicle or fixed object were associated with a high risk of injuries and death, usually due to excessive speed, also correlated to the high level of energy ${ }^{(12)}$.

In addition to the speed, the size (mass) of the vehicle involved also accounts for a significant share of the amount of energy transferred. Hence, higher rates of deaths among motorcyclists involved in accidents with heavy vehicles are expected ${ }^{(13-14)}$.

This study's results did not indicate any association between date and time of the event with deaths; however, when the group of fatalities and survivors (Table 5) are compared, a considerably higher percentage of fatalities is observed on Saturdays and during the night.

The distribution of periods of time in which collisions occurred, analyzed in a study conducted in France, revealed that there were fatalities in $10.7 \%$ of the accidents that occurred during the night; this percentage was $11.2 \%$ on weekends. The authors report that accidents during the night and on weekends result in a high level of mortality ${ }^{(15)}$.

Various national and international epidemiological studies $^{(4,10,16-17)}$ using different methodologies present results both similar and different from those found in this study when the period of time in which the collision occurred is analyzed. International studies indicate Sunday presents a high frequency of traffic collisions, a result that differ from that found by this study. Differences in weather conditions, population habits, and use of motorcycles probably explain these discrepancies. Therefore, regional analyses related to date and time of events are relevant for planning actions and managing the health system.

This study's results indicate that two vehicles were involved in most $(68.0 \%)$ of the events; mortality was similar when one, two or more vehicles were involved. The speed and type of impact of the vehicles involved in a traffic collision probably account more for mortality than the number of vehicles involved.

Failures in the coverage and quality of information recorded in the traffic collision reports hindered the presentation of a more precise scenario. A large amount of data was missing and some important information was insufficiently reported such as: whether the motorcyclist was wearing a helmet at the time of the collision; driver's license status; speed of the vehicle; and driving under the influence of alcohol.

The TCR did not report the speed of the vehicle. The lack of information concerning the drivers' alcohol consumption is probably due to the fact that at the time drivers were legally protected and were not required to test for alcohol consumption.

However, the consulted data sources (TCR and the Institute of Forensic Medicine) are legal documents and as such deserve attention, caution and observation in relation to a correct and efficient completion.

The results obtained in this study corroborate the importance of traffic collisions involving motorcycles and their relationship with motorcyclists' mortality. They revealed important specificities related to the type of accident, type of impact and local conditions, which can contribute to the development and implementation of policies and strategies to reduce motorcycle collisions and improve care programs directed to individuals involved in such events ${ }^{(2-3)}$.

Finally, it is worth noting that a concern was constantly present in the organization of the results and there is an expectation that this study's findings can significantly contribute to the development of interventions aimed to prevent the morbidity and mortality caused by motorcycle collisions.

\section{Conclusion}

In some respects, this study's results corroborate the characteristics of traffic collisions described in the literature but also reveal differences accruing from regional specificities related to local conditions and the use of motorcycles. Collisions with fixed objects, in addition to head-on collisions, heavy vehicles and multiple impacts, stood out in the relationships identified between type of impact and accident and mortality. Inappropriate illumination and collisions in rural areas were more frequently observed in the group of fatalities than among those who survived. We expect the obtained 
results encourage further studies to complement and confirm knowledge acquired so far.

\section{References}

1. Marin L, Queiroz MS. A atualidade dos acidentes de trânsito na era da velocidade: uma visão geral. Cad Saúde Pública. 2000 janeiro-março;16(1):7-21.

2. Oliveira NLB de, Sousa RMC de Diagnóstico de lesões e qualidade de vida de motociclistas, vítimas de acidentes de trânsito. Rev.Latino-Am. Enfermagem. 2003 dezembro;11(6):749-56.

3. Calil AM, Sallum EA, Domingues CA, Nogueira LS. Mapeamento das lesões em vítimas de acidentes de trânsito: revisão sistemática da literatura. Rev. LatinoAm. Enfermagem. 2009 janeiro/fevereiro;17(1):120-5.

4. Rouquayrol MZ, Almeida N Filho. Epidemiologia \& Saúde. 6a ed. São Paulo (SP): Guanabara Koogan; 2003.

5. Organização Mundial da Saúde, Organização Panamericana da Saúde. Classificação estatística internacional de doenças e problemas relacionados à saúde, 10 revisão, v.1. 8a ed. São Paulo: EDUSP; 2000.

6. Bastos $Y$, Gerber L, Andrade SM, Soares DA. Características dos acidentes de trânsito e das vítimas atendidas em serviço pré-hospitalar em cidade do Sul do Brasil, 1997/2000. Cad Saúde Pública. 2005 maiojunho; 21(3):815-22.

7. Gabella B, Reiner KL, Hoffman RE, Cook M, Stallones L. Relationship of helmet use and head injuries among motorcycle crash victims in El Paso, Colorado, 19891990. Accid Anal Prev. 1995 June; 27(3):363-9.

8. Stella J, Sprivulis $P$, Cooke $C$. Head injury related road crash mortality in rural Western Australia. ANZ J Surg. 2001 November; 71(11):665-8.

9. Faria EO, Braga MGC. Propostas para minimizar os riscos de acidentes de trânsito envolvendo crianças e adolescentes. Ciênc Saúde Colet. 1999; 4(1):95-107.

10. Yau KKW. Risk factors affecting the severity of single vehicle traffic accidents in Hong Kong. Accid Anal Prev. 2004 May; 36(3):333-40.

11. Peek-Asa C, Kraus JF. Injuries sustained by motorcycle riders in the approaching turn crash configuration. Accid Anal Prev. 1996 September; 28(5):561-9.

12. Javouhey $E$, Guérin AC, Chiron M. Incidence and risk factors of severe traumatic brain injury resulting from road accidents: a population-based study. Accid Anal Prev. 2006 March; 38(2):225-33.

13. Andrade SM, Mello Jorge MHP. Acidentes de transporte terrestre em cidade da Região Sul do Brasil: avaliação da cobertura e qualidade dos dados. Cad Saúde Pública. 2001 novembro-dezembro; 17(6):1449-56.

14. Jolly BT. Bigger is better, but not for everyone [commentary]. Ann Emerg Med. 1997 August; 30(2):225-6.

15. Reynaud $M$, Le Breton $P$, Gilot $B$, Vervialle $F$, Falissard $B$. Alcohol is the main factor in excess traffic accident fatalities in France. Alcohol Clin Exp Res. 2002 Dec;26(12): 1833-9.

16. Nakahara S, Chadbunchachai W, Ichikawa M, Tipsuntornsak N, Wakai S. Temporal distribution of motorcyclist injuries and risk of fatalities in relation to age, helmet use and riding while intoxicated in Khon Kaen, Thailand. Accid Anal Prev. 2005 Sept;37(5): 833-42.

17. Pereira WAP, Lima MADS. Atendimento pré-hospitalar: caracterização das ocorrências de acidente de trânsito. Acta Paul Enferm. 2006 jul/set; 19(3):279-83. 